\section{EUROPE}

\section{First meeting}

THE problem of disclosure of information emerged last week as the most immediate obstacle to progress in formulating European guidelines for recombinant DNA research when representatives of bodies in some 15 European countries concerned with its regulation met in Strasbourg under the European Science Foundation's wing.

The meeting, the first of the newly established European Committee on Recombinant DNA, was from all accounts very useful and friendly but far too short to allow adequate discussion of a heavy agenda. The disclosure issue concerned the details which need to be revealed about particular projects in order that guidelines might be formulated and containment procedures applied without the applicant surrender ing scientific or commercial advantage.

The simple origin of the problem is the recommendations of the committee's predecessor. This concluded last year that the recommendations and code of practice of the British Williams report should be adopted as guidelines for recombinant DNA research in Europe. The difficulties arise because those recommendations are general rather than specific, emphasise physical more than biological containment, and operate in a country where agreed standards of confidence obtain and certain patent laws operate.

Since only a body of case law can fill in the grey areas created by the lack of specificity, the argument goes, access to full details of particular cases becomes necessary for everyone using the guidelines, particularly where biological containment allows a drop in the level of physical containment. The trouble is, in Britain disclosure of such detail apparently means forfeiting the right to apply for a patent, and the hard-towin cooperation of such companies as ICI with Britain's Genetic Manipulation Advisory Group (GMAG) must be on the understanding that revelations to it will not constitute disclosure.

Whether that means that without full disclosure the Williams guidelines could not operate fairly is unclear, but it is apparent that Britain's patent laws, interpreted in this way, could create a problem nationally and certainly internationally. The position is different in the United States, where application for a patent can be filed up to 12 months following disclosure.

In Strasbourg the French and Swedish representatives urged full disclosure, and the representative of Britain's GMAG was not in a position to agree. That means that answers are needed on the precise meaning of Britain's patent laws as they relate to recombinant DNA research before the next meeting expected in September.

No one seems to doubt that there should be a full exchange of information for any European guidelines to work properly. But the potential economic rewards of the work (the bad experience of penicillin is not lost in Britain) are also recognised, and if industry is to be incorporated in the whole scheme without resort to legislation, it may be at the price of not having full disclosure. In that case, the idea of using paradigmatic cases will gather support.

Chris Sherwell

BRITAIN

\title{
Sea-bed disposal: safe after all?
}

An optimistic assessment of the radiological consequences of disposing of solid high-level radioactive waste on the ocean floor is published this week. Chris Sherwell reports

IMAGINE it is the year 2010. The world's nuclear power programme, consisting entirely of light water reactors, had an installed electrical generating capacity ten years earlier of 2,500 GW. The high-level waste produced by that programme has since been cooling in ponds at a reprocessing site, and has now been glassified and put into stainless steel cylinders with 'waste oxide incorporation'. The cylinders-all 72,000 of them-are about to be dumped on the floor of the North Atlantic, in one operation. What will happen over the next 1,000 million years?

An attempt to answer that question is contained in a report out this week from the National Radiological Protection Board (NRPB)* and prepared for British Nuclear Fuels Ltd (BNFL). The subject is especially controversial at the moment in Britain where, apart from the decisions being sought on the choice of the next generation reactor and on the commitment to the fast breeder, the matters of oxide fuel reprocessing and of high-level waste disposal remain unresolved issues.

Just last week, for example, the UK Atomic Energy Authority (UKAEA) attached great importance to the words of Dr Frank Feates, head of Harwell's Environmental Safety Group, at a public meeting in Scotland. The search now being conducted was not for dumping grounds in any particular area, he said; it was to see if unfissured granite, no matter where it was, was a safe structure for high-level waste disposal.

The idea of underground burial, which is being investigated in other countries too and focuses on salt and clay as well as granite, is only one of three options. The others are burial under the ocean floor and placement on the ocean floor, and it is the consequences of the latter alone which the NRPB study examines, even though the London Convention of 1972, which came into force in 1975, expressly forbids such disposal-a point the study mentions in an appendix.

The report endeavours to model the ways in which material deposited on

*P. D. Grimwood and G. A. M. Webb, Assessment of the Radiological Protection Aspects of Disposal of High Level Waste on the Ocean Floor. (NRPB-R48, HMSO, 50p). the ocean floor will re-enter man's immediate environment, especially via his food. The principal route of return it uses is via dispersion in the deep ocean, physical transport to the productive surface layers, incorporation in marine food chains and the consumption of contaminated seafood, but it also considers radiation doses arising from contamination of beach sediments.

Although the report emphasises that only broad conclusions should be drawn, it states that "no overriding reason connected with radiological protection considerations has been identified which would preclude the disposal of suitably conditioned high-level waste on the ocean floor'. Other points :

- All the vitrified waste may be expected to be dissolved in about 3,500 years. The heat generated by the wastes would not give rise to "any significant vertical transport mechanism". The amount of activity removed from the water by adsorption onto sediments will not be the major fraction of the total amount released, and will not significantly deplete the quantity of activity in the water, for $10^{5}-10^{6}$ years. - Assessments, for each of the many nuclides involved, of their changing concentrations over time in surface and deeper waters, and of how these are take up by plankton, molluscs, crustacea, fish and eventually man, show the relative importance of different routes. The ratio of intake to the maximum permissible annual intake (I/MPAI) attains its highest value for consumption of deep-ocean fish or plankton (neither of which routes currently exist) at times of either 50100 years or $500-2,000$ years. The ratio is $10^{-2}$; for surface fish, the order is $10^{-4}$; other ratios are below $10^{-5}$.

- The largest annual collective dose is due to consumption of surface fish (the only intake route actually established), at about $4 \times 10^{4}$ man rems at 50 years from ${ }^{137} \mathrm{Cs}$ and ${ }^{90} \mathrm{Sr}$ taken together. Collective doses at longer times will be of the order of $10^{2}-10^{3}$ man rems per year. The figures would be larger if plankton was established as a major direct food source.

- Predictions of nuclide levels in the sea water do not exceed the level of the nuclides known to be present in sea-water naturally or through fall-out.

The study emphasises that different conclusions might be reached if the waste was separable into short- and long-lived fractions, if a different composition (or even monolithic) glass was available, if better containment materials than steel were used, or if additional barriers, including even the sediment itself, were employed. 